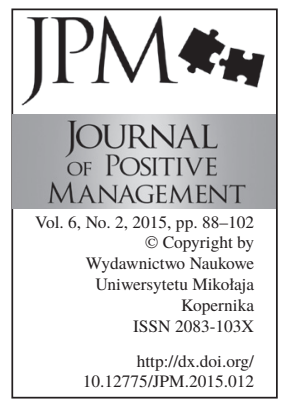

\title{
THE MEANING OF STEREOTYPES IN THE WORKPLACE IN RESPECT OF EMPLOYABILITY
}

\author{
Izabela Bednarska-Wnuk ${ }^{\mathrm{a}}$, Marzena Syper-Jędrzejak ${ }^{\mathrm{b}}$ \\ ${ }^{a}$ University of Lodz, Department of Management, Lodz, Poland \\ ${ }^{\mathrm{b}}$ University of Lodz, Department of Human Resources Management, \\ Lodz, Poland \\ a e-mail: iwnuk@uni.lodz.pl \\ be-mail: marzenasyper@wp.pl
}

\begin{abstract}
Purpose: The main purpose of this article is to present the stereotypes which - to the authors' mind - are the most common on the Polish labour market and their relation to employability.

Methodology/approach: The basic methodological approach profited from in this article is descriptive and has been on literature.

Findings: The article can serve as inspiration to break down stereotypes regardless of the geographical location of the organization. It can also contribute to growth and the change of the perception of own employability.

Implications/limitations: The paper aims to show how stereotypes at work can affect employability. But it would be advisable to perform profound empirical studies, revealing the relationships between an individual's employability and stereotypes in the workplace. On the other hand, however, this issue would be an extremely challenging research process due to the ambiguity of stereotype category in a theoretical view.
\end{abstract}

Originality/value: The article includes recommendations for practical application drawn from theoretical reflections, which can be an inspiration to break stereotypes and contribute to the increase and alteration of perceived employability.

Keywords: organizational behaviour, human in the organization, stereotypes in the workplace, employability

Paper Type: Viewpoint

\section{Introduction}

In the labour market those who are seeking employment, or are already part of the corporate structure, must possess specified features and skills that give them the ability to get and keep a satisfying job (Hillage and Pollard, 1998). This is closely related to the concept of employability, which - in the circumstances where an organisation is no longer capable of guaranteeing long-term employment 
and cannot be responsible for an individual's professional development - should become an element of the brand new psychological contract between the employee and the employer (Marzec, 2010). Nowadays, it is employees that become the architects of their own career path, taking care of their own job security (Van der Heijden and Bakker, 2011).

The level of employability may be influenced by a number of factors: individual, organisational, directly related to work or situational (Berntson, 2008). Apart from the aforementioned issues, the stereotypes cultivated by employers are another significant factor influencing the level of employability. These stereotypes can effectively distort an individual's image, regardless of their personal endeavours, and thus influence the perceived employability and employees' discriminatory behaviour (Janowska, 2010). This refers, in particular, to stereotypes related to physical attractiveness, sex, assigned social roles and disability. Naturally, there are other stereotypes which also restrict the chances of employment and professional development on the labour market. However, due to their limited manifestation (the Polish labour market is relatively homogeneous as far as the ethnic or religious background of the workforce is concerned), the scope of their influence is respectively lesser. Of course, the direction of change currently taking place leads to the assumption that diversity in Polish companies in these respects will rise significantly.

Taking into account the aforementioned deliberations, the main purpose of this article is to present the stereotypes which - to the authors' mind - are the most common on the Polish labour market and their relation to employability, on the basis of a literature review. Additionally, the publication includes some a major recommendations for practical application drawn from theoretical reflections, which can possibly be an inspiration to break stereotypes and may contribute to the increase and alteration of perceived employability.

\section{The essence of the stereotype}

The concept of 'stereotype' etymologically comes from Greek, where the word stereós means 'solid', 'hard', 'massive', and typos - 'impress' or 'pattern' (Chlewiński and Klucz, 1992). Walter Lippmann, who coined the term 'stereotype', played the main role in the development of its sociological theory, by defining it as the "projection upon the world of our own sense of our own value, our own position and our own rights' (Lipmann, 1998). Lippmann compared a stereotype to a green window pane through which the displayed object can only be seen in green light. This metaphor leads us to the temporary definition of the concept applied in modern psychology (Mandal, 2004), where stereotypes are interpreted as simplified imaginations and beliefs which are emotional and judgmental in nature, shared by the members of a group or community and expressed in a verbal, figurative or symbolic fashion (Mudyń, 1998). This definition refers to patterns
THE MEANING OF STEREOTYPES IN THE WORKPLACE

Izabela Bednarska-Wnuk Marzena Syper-Jędrzejak 
THE MEANING OF STEREOTYPES IN THE WORKPLACE

Izabela Bednarska-Wnuk Marzena Syper-Jędrzejak representing a group or people selected by any specific, easily noticeable feature that determines their social identity (Wojciszke, 2004). Today a stereotype is understood as a generalization referring to a group, where identical features are attributed to all its members, regardless of the actual differences between them (Aronson et al., 1997). Therefore, the perception of a stereotype as an exclusively negative phenomenon is being abandoned, as - on numerous occasions - they are considered useful. In this approach, stereotypes sometimes provide an individual with hints on how to behave in any given social circumstances and in contact with particular social groups (Stephan and Stephan, 2007).

G. Allport described stereotyping as "law of less effort" - people have a limited ability to process information, so they use cognitive shortcuts and apply some practical rules when attempting to understand the others. As long as the resulting stereotype stems from experience and is generally adequate, it is a form of dealing with the excess of stimuli that we encounter every day. Sometimes, however, stereotype makes it difficult to perceive particular persons as individual and original entities - and thus it begins to pose a problem for a person using it, as well as for the environment (Aronson et al., 1997). Simplification of the obtained information, due to the use of the stereotype, meets the needs for explaining the world and prediction, and protects individual values. For groups, stereotypes allow for avoiding or mitigating the fear of change and the unknown, resulting from the attachment to the current situation or pursued lifestyle. Another function of the stereotype is creation of the basis for a process of self-identification of an individual - stereotypes provide people with knowledge of the important components of their own "I". Moreover, the stereotype is a kind of cultural heritage, as a kind of common knowledge of the species, which allowed in the past and still allows survival (Mandal, 2004).

The process of stereotype acquisition is connected with the long-term socialization of humans, and the 'ready-made' convictions regarding traits, predispositions and inclinations of various groups are implemented in the period of adolescence. According to Mackie, 'we learn stereotypes', adopting them from society (Macrae et al., 1997).

\section{Employability - theoretical deliberations}

Nowadays, the uncertainty on the labour market has triggered debates on the issue of employability (Van Selm and Van der Heijden, 2013; Van der Heijden and Bakker, 2011; Hillage and Pollard, 1998), a term which is the combination of the words 'employment' and 'ability', and which describes one's ability to be employed (Vanhercke et al., 2014). In the context of Poland, it is, however, quite a challenge to present a literal translation of the term. Therefore, it is most commonly interpreted as attractive employment perceived from two different points of view: the employee's and the employer's (Sienkiewicz, 2010). 
The term began to appear in the subject literature as early as in the 1950's, and ever since has been under scrutiny of theoreticians and practitioners (Van der Heijde and Van der Heijden, 2006). The term of employability has evolved and its various aspects have been analysed and researched (Berntson, 2008). Initially, it was scrutinised from a macroeconomic perspective and focused on the issue of unemployment and the difficulties of the unemployed in finding a job. In later years, employability was identified with an employee's adjustability to the requirements of any given profession, i.e. their professional suitability (Marzec, 2010). Currently the microeconomic perspective is emphasised (referring to the organisation and the individual), where the concept of employability is examined in relation to an individual's professional development on the external and internal labour market and emphasises the actions aimed at the enhancement of employability (Wiśniewska, 2015).

In the literature, there are numerous definitions of employability that focus on its miscellaneous attributes. Some are based on the conceptual approach (Van der Heijde and Van der Heijden, 2006; York and Knight, 2006, Saha et al., 2013) which relate employability to 'permanently fulfilling, acquiring or creating work through the optimal use of competencies' (Van der Heijde and Van der Heijden, 2006), while others focus on abilities, personal features, skills and knowledge that influence an individual's employability, thus determining his or her attractiveness on the labour market (Vanhercke et al., 2014; Berntson, 2008). For instance, Berntson and Marklund (2007) define employability as 'the individual's perception of his or her possibilities to get a new job'.

Having analysed the relevant subject literature, Sienkiewicz singled out several categories of employability, depending on the applied perspective (Sienkiewicz, 2010). These are, for instance, definitions focusing on employability understood as (Sienkiewicz, 2010):

- a set of features and attributes possessed by an individual,

- an ability to find and keep work,

- an ability to demonstrate features and skills to potential employers or their practical application,

- the specific transactional nature of the employer-employee relationship,

- personal responsibility, including the specificity of any given labour market,

- a negative term - as a trend or slogan.

Wiśniewska, on the other hand, treats the term of employability in its narrow and broad meanings. As far as the narrow approach is concerned, the concept of employability refers to skills that in a specified amount of time render any given individual more attractive to employers. The broad approach, however, defines employability in the context of a new psychological contract and is connected not only with gaining but also with keeping a job in the long run (Wiśniewska, 2015).
THE MEANING OF STEREOTYPES IN THE WORKPLACE

Izabela Bednarska-Wnuk Marzena Syper-Jędrzejak 
THE MEANING OF STEREOTYPES IN THE WORKPLACE

Izabela Bednarska-Wnuk Marzena Syper-Jędrzejak
On the grounds of psychology, employability is scrutinised in respect of perception since - as claimed by Vanhercke, De Cuyper, Peeters, De Witte (2014) - it reflects the focusing of the term on an individual level and accentuates the subjectivity of man. The perceived employability is an individual perception, the perception of one's chances and abilities on the labour market as well as the possibility to gain and keep one's current job (Berntson and Marklund, 2007). This approach bears a resemblance to the aforementioned definitions: the approach based on competences and on the perception of natural persons. The differences, however, manifest themselves in an alternate perception of employment by miscellaneous groups on the labour market and at various stages of their career paths (Vanhercke et al., 2014). On the other hand, one's own employability is most commonly seen through individual features (demographic factors, skills and knowledge) (Berntson, 2008), while its interpretation may turn out to be different for each individual. The authors of this publication also argue that stereotypes related to physical attractiveness (Hosoda et al., 2003), sex (Agars, 2004), age (Van Selm and Van der Heijden, 2013), assigned social roles (Warzecha, 2014) and disability (Scott, 1995; Watermeyer, 2014) are also significant factors influencing the perceived employability. The stereotypes listed above may be of great importance, especially in respect of employability in Poland, where such events as the political transformation and the accession of Poland to the European Union have resulted in the growth of social awareness of the continuous necessity to develop and expand the education of knowledge and competences of Polish entrepreneurs and employees in order to meet the requirements of the modern knowledge-based economy (Marzec, 2009).

\section{Stereotypes in the workplace and employability}

Stereotypes influence the perception of another man, and how information related to his traits and behaviour is processed, stored and remembered (Macrae et al., 1999). As mental constructs, they contribute to the making of conducts and relations in various types of institutions and enterprises. There is also a number of stereotypes that make it difficult for the members of the affected groups to perform their role or function, e.g. the stereotype of the affectionate, emotional and delicate woman who is just 'unfit' to occupy a managerial position and succeed in so called 'male professions' (Mandal, 2004). This is related to the fact that individuals are attributed with various professional values, developed as an image of personal observations or adaptation of different attitudes created in a social context. In the professional sphere (and not only there) stereotypes may also draw a simplified picture of reality and influence the perceived employability, chiefly in regard to the interpretation of one's own prospects on the labour market. Thus, people representing a similar professional profile may have different perceived employability, based on the knowledge on the labour market and/or the assessment provided by others which is often distorted by stereotypes. 
As mentioned above, the article distinguishes several categories of stereotypes which are typical in Poland and can, in their peculiar manner, obstruct the normal functioning of an individual in their workplace and limit their perceived employability. These categories include stereotypes related to physical attractiveness, sex, age and disability.

One of the most significant stereotypes that impact our functioning in social and professional life is the one related to our physical attractiveness. It originates from the statement 'what is beautiful must also be good', according to which attractive people are attributed with various positive traits and features (Dion et al., 1972). As pointed out by Jarmuż (Jarmuż, 2007), in numerous psychological studies there is a substantial amount of data on the perception of the influence that physical attractiveness has upon the opinion of other individuals. In the professional context it can be noted that physical attractiveness has an impact on employment decisions and, most importantly, upon the phase of initial assessment of a potential employee. Physical attractiveness may also be decisive as far as promotion is concerned, especially in the situation where numerous candidates boasting comparable achievements are being assessed. Another interesting fact is that attractive people generally record higher yearly incomes in comparison to those less attractive. This, however, refers to men and older people, and is common in typically male professions (Jarmuż, 2007). Studies on the influence exerted by the stereotype of physical attractiveness in the workplace also confirm that, when compared to less physically attractive candidates, attractive ones are perceived as being better qualified (Bardack and McAndrew, 1985; Beehr and Gilmore, 1982), are assessed and treated better (Hosoda et al., 2003), and are more likely to be professionally successful (LoSardo, 2014).

In the subject literature, slightly greater attention is paid to sex-related stereotypes in the professional context (Cabrera et al., 2009). According to Grabowska, this process seemingly occurs at the wider, social level, but not without some negative consequences for the individual level. A division into typically male and female professions is noted, which results in the weakening of the professional identification of women and men, and limits the capacity of self-actualisation in any specific job, in exchange offering greater chances of identification in the stereotypically perceived roles of men and women (Grabowska, 2007). Not only does a stereotypically formulated professional role influence the process of identification, but also personnel selection. Therefore, this is very meaningful as far as gender inequality on the labour market is concerned, since men and women still are not treated equally in the aspect of employment, assessment, promotion and remuneration. Undoubtedly, this stems from the stereotypes related to gender discrimination on the labour market (Warzecha, 2014). The stereotypes related to the social roles of men and women are conditioned culturally and originate from a general assumption on the abilities and predispositions of either sex and
THE MEANING OF STEREOTYPES IN THE WORKPLACE

Izabela Bednarska-Wnuk Marzena Syper-Jędrzejak 
THE MEANING OF STEREOTYPES IN THE WORKPLACE

Izabela Bednarska-Wnuk Marzena Syper-Jędrzejak the specific features attributed to different genders. Thus, women are supposed to be more caring and sensitive to the needs of others, whereas men are considered to be more decisive, emotionally cool, resilient and power orientated. Such stereotypisation has its measurable consequences in the professional context where these stereotypes are activated (White and White, 2006) and it influences the perceived employability. For instance, those women who, during a job interview, emphasise their submission to the interlocutor are more likely to be employed than the ones who demonstrate a more dominating attitude. On the other hand, men who are modest, submissive and show low self-esteem are less likely to be taken on (Warzecha, 2014).

The stereotypes related to assigned social roles frequently become visible in the professional context and contribute to the division of professions into typically 'male' and 'female' jobs, which results in the inequality on the labour market as well as the so called sectoral feminisation (Warzecha, 2014), (in which the employment structure of any given profession is dominated by women) and the masculinisation of some professions. However, while a man with a typically 'female' profession usually raises admiration and respect, a woman involved in a 'male' job frequently suffers from depreciation, as her competences are questioned. This stems from the fact that women are often perceived through the prism of their stereotypical features, e.g. thoughtfulness. Thus, they find it more difficult to hold typically male positions and, even if they eventually succeed in getting one, their results and performance are usually assessed through the stereotype of sex, which translates into them being perceived as less competent, hardworking and committed (Eagly and Mladanic, 1994; after: Rudman and Goodwin, 2004). Taking into account the abovementioned division of professions within the organisational structure, it is also essential to mention the stereotypes related to managerial positions. Even though numerous reports, e.g. the 2014 Report by the Polish Ministry of Labour and Social Policy, show that on a year-to-year basis more and more women hold such positions, they are still by far in the minority in the top ranks (the PMLSP Report, 2014). This, in turn, strengthens the well-established belief on the inequality of the sexes and encourages men to apply for leadership roles, supporting their endeavours and cementing the status quo to an even greater extent (Ibarra, 2014). Here the blame ought to be put on the so called second-generation prejudices, which may not lead to open discrimination, but which still create a specific corporate atmosphere where women cannot fully exploit their potential. These prejudices result in weaker bonds between employees representing the different sexes. At the same time, women are frequently advised to occupy staff or administrative positions in order to compromise between professional and family life, which in the future has a negative influence on the path and dynamics of their career (Crosby after: Ibarra et al., 2014). 
Another group of stereotypes which may significantly impact on an individual's employability are those related to age. As pointed out by van Selm and Van der Heijden, it is reflected in the traditional perception of 'older employees' (Van Selm and Van der Heijden, 2013). Age, along with sex and social class, is one of the most important dimensions determining an individual's social standing. Discriminating against employees and candidates on the basis of their age is called ageism (Szukalski, 2008). In practice, the term and its negative consequences mainly refer to older people (Šolcová, 2011). Ageism aimed at persons of advanced age is based on the conviction that an individual over a particular age is incapable of performing certain social roles in due manner, and especially those which are socially perceived as productive, i.e. professional duties (Szukalski, 2008). At an institutional level, however, ageism is mostly manifested in the sphere of recruitment, human capital investment, promotion and redundancy policies. The scale of the issue on the Polish labour market is considerable - as shown by the research performed among a sample representative group of Polish citizens on behalf of the Government Plenipotentiary for Equal Treatment between 2011-2012, every third interviewee stated that the problem of age discrimination persists. $12 \%$ of the respondents admitted to having been discriminated against on the basis of their age. Additionally, 13\% reported personally knowing another individual over 50 who was a victim of ageism in their workplace (the 2011 Report 'Equal Treatment - a Standard of Good Governance'). Other Polish studies (including Study of Human Capital) indicate that the age of job applicants was important for $83 \%$ employers. The highest acceptable age limit of a candidate for the job in most positions considered according to Polish employers was 45 years, and the age proved to be a more important recruitment criterion than experience (Mockałło, 2015).

The final category of stereotypes discussed in this publication is a set of stereotypes influencing the employability of the disabled. Each society has a certain percentage of people who cannot demonstrate their full physical or mental ability due to an impairment that may be hereditary and inborn, or might have occurred during a person's lifetime as a result of an illness, accident or inappropriate living conditions, and who experience sadness, shame, dependence and the sense of isolation (Watermeyer, 2014). For those groups who, despite their disability, are still capable of being professionally active, employment is of special importance - apart from financial benefits, it provides them with the sense of being useful and needed, and it satisfies their desire for acceptance, independence or self-sufficiency. In numerous cases, the lack of objective 'contraindications' for employment is outweighed by strong stereotypes regarding the disabled, which to a great extent lower their employability and limit their chances of professional development. The results of the research carried out by the Centre for Public Opinion Research (TNS OBOP) on behalf of the Polish Organisation
THE MEANING OF STEREOTYPES IN THE WORKPLACE

Izabela Bednarska-Wnuk Marzena Syper-Jędrzejak 
THE MEANING OF STEREOTYPES IN THE WORKPLACE

Izabela Bednarska-Wnuk Marzena Syper-Jędrzejak

Figure 1. The consequences of stereotypes in the workplace for employability

Source: authors' own elaboration. of Employers of the Disabled (POPON) (Gorajewska, 2009) reveal a stereotypical image of a disabled person who is believed to be less efficient, more prone to illness, requires expensive disabled facilities and privileges in the workplace, and is generally 'problematic' and ineffective from the potential employer's point of view. All this may be accompanied by the aspect of possible discomfort (e.g. fear, disgust) on the part of clients and colleagues who have contact with the disabled person. According to the aforementioned report, $49 \%$ of the respondents believe that in Poland people fall victim to discrimination based on their psychosexual orientation, over $40 \%$ notice the issue of racial discrimination, and every fourth respondent sees indications of religious discrimination (the 2011 Report 'Equal Treatment - a Standard of Good Governance').

The relationships between stereotypes and employability, as indicated in Figure 1, are meaningful not only to individuals, but also to organisations.

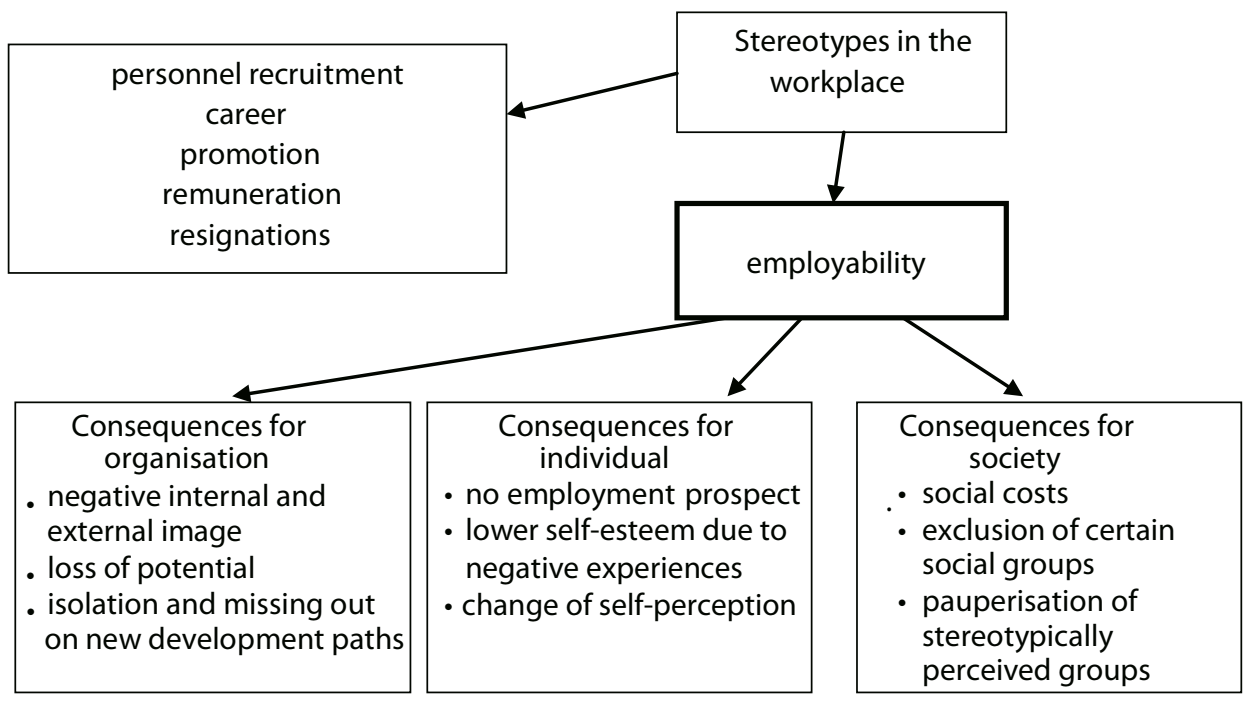

Furthermore, the social consequences of this phenomenon must not be ignored either, since they obstruct the chances of development for certain groups, excluding them from the mainstream and condemning them to a lesser professional, financial and, finally, social position.

\section{Conclusions and recommendations for organizational practice}

Personnel recruitment and selection, and promotion and career policies are, in particular, among the sub-processes most sensitive to the influence of stereotypes, since this is when a supervisor or an HR decision-maker evaluates not only the 
qualifications and achievements of a candidate to be employed or promoted, but also his or her other traits and features such as personality, behaviour, potential for success or the broadly understood suitability for the organization. Similarly, in the course of one's further professional activity, stereotypes in the company may also directly influence the image of an individual in the professional context, effectively distorting their reception (e.g. among colleagues, contracting parties or clients) and limiting the broadly understood employability (Wiśniewska, 2015). It should be stated, however, that the influence stereotypes have upon employability is not always unambiguous and negative, since the stereotype itself may be a positive and a negative conviction, i.e. an individual may benefit from its presence, for example in the case of particularly attractive people (Dion et al., 1972; Hamermesh, 2011). Nevertheless, this publication focuses on the consequences of stereotypes that affect employability in a negative manner.

Experience shows that in the recruitment process a candidate whose background may, for various reasons, 'trigger' stereotypes negatively influencing his employability (e.g. a woman, an older person, etc.), is highly unlikely to overcome them as, among other things, there is usually too little time to win over the company's representative during the relatively short period of a job interview. An already employed worker, however, stands in a more privileged position here, as in the course of their daily working routine they are offered the opportunity to make their employer and colleagues conscious of how unjust, detrimental and untrue stereotypical assumptions may be. Therefore, in order to restrict the influence of stereotypes and, at the same time, utilise candidates' various resources, skills and talents to a larger extent, organisations should implement appropriate measures. It ought to be noted that the effectiveness of such measures depends also on broader conditionings: social background and legal and economic conditions (Table 1). And example of such measures are, inter alia, national intervention programmes aimed at fighting stereotypical convictions, and expanding knowledge on, for instance, older employees. Such programmes are part of the governmental programme related to the reduction of stereotypes in the workplace (Van Selm and Van der Heijden, 2013).

One such measure, at the organisational level, is the development of a culture open to corporate diversity, where 'diversity' is understood as the utilisation of human potential present in employees of various genders, ages, backgrounds, religions, health conditions, etc. Pressure on the development of all the employed, linking business incentives and internal decisions made by the management, and the recognition of equality as the most fundamental principle, are all key features of diversity management in the corporate structure (Kandola and Fullerton, 1998; after: Diversity Index). It is also worth emphasising that diversity management is an essential constituent of corporate social responsibility. Appreciation and respect for employees' diversity is one of the most crucial corporate values aimed
THE MEANING OF STEREOTYPES IN THE WORKPLACE

Izabela Bednarska-Wnuk Marzena Syper-Jędrzejak 
THE MEANING OF STEREOTYPES IN THE WORKPLACE

Izabela Bednarska-Wnuk Marzena Syper-Jędrzejak

Table 1. Measures taken to reduce stereotypes in the workplace

Source: authors' own elaboration based on Van Selm and Van der Heijden, 2013; Mockałło, 2015; www. przedsiebiorstwo. fairplay.pl. at sustainable development (Diversity Index). It must be explicitly stressed that the most fundamental purpose of diversity management lies in the development of such working conditions where all employees, regardless of the abovementioned sources of their diversity, are respected, appreciated and offered an opportunity to fully exploit their potential (Lewicka, 2010). Diversity management fits in an extended process of shaping corporate culture, following the idea of openness to diversity and the provision of equal opportunities. From the corporate point of view, such an approach stems from applying the assumption that greater diversity of the employed translates into a wider range of competences and skills at the company's disposal and, thus, it facilitates the optimum use of employees' talents and potential (Diversity Index).

The abovementioned processes can be supported by more formalised solutions, regulating appropriate behaviour and attitudes towards representatives of those groups which are prone to stereotypisation (Table 1). Such solutions may include relevant stipulations in Rules of Work Procedures, Codes of Good Practice, Ethics Charters, etc., as well as precisely determined rules of conduct in employee handbooks or conduct guidelines (e.g. regarding the conduct of solving sensitive issues) or the appointment of a special corporate body responsible for the co-ordination and promotion of equality issues, equal treatment of minorities, and the development of an anti-discrimination policy (Equity Ombudsman, a dedicated helpline, a complaint box, etc.).

legal regulations concerning equal opportunities for all participants of the labour market, anti-discrimination laws, legal protection of groups that are particularly prone/susceptible to stereotypisation

promotion of equal opportunities on the labour market - governmental and

Macro level regional programmes

social campaigns against stereotypes

work of institutions/bodies/foundations established to fight for equal opportunities on the labour market

educational offer for current and future representatives of the labour market

internal regulations and procedures aimed against stereotypes in the workplace

the development of a culture open to diversity of human capital - diversity

Organisational management

level training courses for employees and management

the modelling of appropriate attitudes initiated by the management and HR decision-makers

There is one more aspect which must be mentioned at this point. The fact is that even the best designed procedures will return no desired results unless the company's management becomes involved in the struggle against stereotypes, by 
giving a personal example of behaviour compliant with the declared standards. This can be performed through the modelling of attitudes, whose purpose is to teach and support employees in their functioning within a heterogeneous working environment. The management can modify the attitudes of its employees mainly by means of persuasion, positive and negative reinforcement, various learning mechanisms and techniques, use of social pressure or activation methods such as workshops and training sessions. It is the methods related to the personal development of employees within the organisation that are a very specific form of stereotype prevention in the workplace, since not only do they influence the acquisition of new knowledge, but also they can modify the attitudes of the employees in the direction desired by the management.

In conclusion, it should be noted that, due to the complexity of the discussed issue, the presentation of theoretical divagations does not exhaust the subject. Certainly, it would be advisable to perform profound empirical studies, revealing the relationships between an individual's employability and stereotypes in the workplace. On the other hand, however, this issue would be an extremely challenging research process due to the ambiguity of stereotype category in a theoretical view. It would be of particular interest to analyse the extent to which the initiatives for combating stereotypes (Table 1), separated in the text, improve employability of people from groups vulnerable to stereotypes. Since, assumedly, the effectiveness of these measures depends on social and economic factors and legal conditions, the next point of research would be to check the impact of particular conditions on the efficiency of operations. Nevertheless, the divagations presented above, including recommendations for practical application, may constitute a vital catalogue of actions aimed at improving the general functioning of an individual in their workplace and influencing their perceived employability on the modern labour market.

\section{References}

Agars, M. D. (2004), "Reconsidering the impact of gender stereotypes on the advancement of women in organizations", Psychology of Women Quarterly, Vol. 28 No. 2, pp. 103-111. DOI: http://dx.doi.org/10.1111/j.1471-6402.2004.00127.x.

Aronson, E., Wilson, T. D., Akert, R. M. (1997), Psychologia społeczna. Serce i umyst, Wydawnictwo Zysk i S-ka, Poznań.

Bardack, N. R., McAndrew, F. T. (1985), "The influence of physical attractiveness and manner of dress on success in a simulated personnel decision", The Journal of Social Psychology, Vol. 125 No. 6, pp. 777-778.

Beehr, T. A., Gilmore, D. C. (1982), "Applicant Attractiveness as a Perceived Job Relevant Variable in Selection of Management Trainees", Academy of Management Journal, Vol. 25 No. 3, pp. 607-617. DOI: http://dx.doi.org/10,2307/256084
THE MEANING OF STEREOTYPES IN THE WORKPLACE

Izabela Bednarska-Wnuk Marzena Syper-Jędrzejak 
THE MEANING OF STEREOTYPES IN THE WORKPLACE

Izabela Bednarska-Wnuk Marzena Syper-Jędrzejak
Berntson, E. (2008), Employability perceptions: Nature determinants and implications for Health and well-being, Stockholm University, Stockholm.

Berntson, E., Marklund, S. (2007), "The relationship between perceived employability and subsequent health", Work\&Stress, Vol. 21 No. 3, pp. 279-292. DOI: http://dx.doi. org/10.1080/02678370701659215

Cabrera, S. F., Sauer, S. J., Thomas-Hunt, M. C. (2009), “The Evolving Manager Stereotype: The Effects of Industry Gender Typing on Performance Expectations for Leaders and Their Teams", Psychology of Women Quarterly, Vol. 33 No. 4, pp. 419-428. DOI: http:dx.doi.org/10.1111/j.1471-6402.2009.01519.x

Chlewiński, Z., Kucz, I. (1992), Stereotypy i uprzedzenia, Instytut Psychologii PAN, Warszawa.

Dion, K., Berscheid, E., Walster, E. (1972), "What is beautiful is good", Journal of Personality and Social Psychology, Vol. 24 No 3, pp. 303-305.

Diversity Index, (2013), Zarzq̨dzanie różnorodnościq w miejscu pracy - Raport z I edycji Barometru Różnorodności, available at: http://www.diversityindex.pl/pdf (accessed 17 August 2015).

Eagly, A. H., Mladinic, A. (1994), "Are people prejudiced against women? Some answers from research on attitudes, gender stereotypes, and judgments of competence", in: Stroebe, W., Hewstone, M. (Eds.), European review of social psychology, Vol. 5, pp. 1-35, after Rudman, L. A., Goodwin, S. A. (2004), "Gender Differences in Automatic In-Group Bias: Why Do Women Like Women More Than Men Like Men?", Journal of Personality and Social Psychology, Vol. 87 No. 4, pp. 494-509. DOI: http:dx.doi.org/10.1037/0022-3514.87.4.494

Grabowska, M. (2007), Stereotypy płci we wczesnej dorosłości, Wybrane Uwarunkowania, Wydawnictwo UKW, Bydgoszcz.

Gorajewska, D. (2009), Fakty i mity o osobach z niepetnosprawnościa, Wydawnictwo Stowarzyszenia Przyjaciół Integracji, Warszawa.

Hamermesh, D. S. (2011), Beauty pays: Why attractive people are more successful, Princeton University Press, New Jersey.

Hillage, J., Pollard, E. (1998), Employability: developing a Framework for Policy analysis, Research Report No. 85, Department for Education and Employment, London.

Hosoda, M., Stone-Romero, E. F., Coats, G. (2003), "The Effects of Physical Attractiveness on Job" Related Outcomes: A Meta "Analysis of Experimental Studies", Personnel Psychology, Vol. 56 No. 2, pp. 431-462. DOI: http:dx.doi/ org/10.1111/j.1744-6570.2003.tb00157.x

Ibarra, H. (2014), "Niewidzialne bariery w drodze na szczyt", Harvard Business Review Polska, Vol. 1 No. 1, pp. 41-49.

Janowska, Z. (2010), Zarzązanie zasobami ludzkimi, Polskie Wydawnictwo Ekonomiczne, Warszawa.

Jarmuż, S. (2007), "Czy piękne jest dobre? Złudzenie w doborze i ocenie personelu", in: Witkowski, T. (Ed.), Dobór personelu. Koncepcje-narzędzia-konteksty, Biblioteka Moderatora, Taszów, pp. 21-30.

Lippmann, W. (1998), Public Opinion with a new introduction by Michael Curtis, Transaction Publishers, New Jersey. 
Lewicka, D. (2010), Zarządzanie kapitałem ludzkim w polskich przedsiębiorstwach, PWN, Warszawa.

LoSardo, D. (2014), “The Influence of Physical Attractiveness in Pre-Employment Selection Decisions", available at: http://thesis.haverford.edu/dspace/handle/10066/14712, (accesed 22 July 2015).

Macrae, C. N., Stangor, Ch., Hewstone, M. (1999), Stereotypy i uprzedzenia, Gdańskie Wydawnictwo Psychologiczne, Gdańsk.

Mandal, E. (2004), Podmiotowe i interpersonalne konsekwencje stereotypów zwiqzanych z ptcia, Wydawnictwo Uniwersytetu Śląskiego, Katowice.

Marzec, I. (2010), "Zatrudnialność jako czynnik bezpieczeństwa zatrudnienia i sukcesu na współczesnym rynku pracy", Zeszyty Naukowe Wyższej Szkoły Zarządzania Ochrona Pracy w Katowicach, Vol. 1 No. 6, pp. 127-138.

Marzec, I., Van der Heijden, B. I. J. M, Scholarios, D., Van der Schoot, E., Jędrzejowicz, P., Bozionelos, N., Epitropaki O., Knauth, P., Mikkelsen, A., Van der Heijde, C. (2009), "Employability management practices in the Polish ICT sector", Human Resource Development International, Vol. 12 No. 5, pp. 471-492. DOI: http://dx.doi. org/10,1080 / 13678860903274539

Mockałło, Z. (2015), "Stereotypy na temat starszych pracowników i ich związek z dobrostanem oraz pracą - przegląd badań”, Bezpieczeństwo Pracy, No 4, pp. 11-13.

Mudyń, K. (1998), "Stereotypy”, in: Szewczuk W. (Ed.), Encyklopedia Psychologii, Fundacja Innowacja, Warszawa.

Przedsiębiorstwo Fair Play, available at: www.przedsiebiorstwo.fairplay.pl (accessed 07 August 2015).

Raport, (2015), "Równe Traktowanie Standardem Dobrego Rządzenia", available at: http://www.siecrownosci.gov.pl/aktualnosci/art,299, raport-z-badan-sondazowychprowadzonych-w-ramach-projektu-rowne-traktowanie-standardem-dobrego-rzadzenia.html (accessed 20 August 2015).

Raport Ministerstwa Pracy i Polityki Społecznej, (2014), “Więcej równości - więcej korzyści w gospodarce Kobiety i mężczyźni na stanowiskach decyzyjnych w polskiej gospodarce w latach 2010-2013", available at: http://rownoscwbiznesie.mpips. gov.pl/jdownloads/Pliki\%20do\%20pobrania/wicej_rwnoci_wicej_korzyci_w_gospodarce_skrt_raportu.pdf (accessed 27 August 2015).

Rynek pracy, (2015), available at: http://www.niepelnosprawni.gov.pl/niepelnosprawnoscw-liczbach-/rynek-pracy/, (accessed 28 August 2015).

Saha, N., Van der Heijden, B. I. J. M., Gregar, A. (2013), "Strategy and policy in mobilizing resources for employability enhancement (West Bengal, India)", International Journal of Education and Information Technologies, Vol. 1 No. 7, pp. 18-26.

Scott, G. (1995), Discrimination. Prejudice in Action. Multicultural Issues, Reports Evaluative, Enslow Publishers, Springfield.

Sienkiewicz, Ł. (2010), “Atrakcyjność zatrudnieniowa. Problemy definicyjne i ich konsekwencje”, Edukacja Ekonomistów i Menedżerów. Problemy. Innowacje. Projekty, Vol. 2 No. 16, pp. 27-43.

Šolcová, I. (2011), "Psychosocial aspects of aging”, Ceskoslovenska Psychologie, Vol. 56 No. 2, pp. 152-166.
THE MEANING OF STEREOTYPES IN THE WORKPLACE

Izabela Bednarska-Wnuk Marzena Syper-Jędrzejak 
THE MEANING OF STEREOTYPES IN THE WORKPLACE

Izabela Bednarska-Wnuk Marzena Syper-Jędrzejak
Stephan, W. G., Stephan, C. W. (2007), Wywieranie wptywu przez grupy. Psychologia relacji, Gdańskie Wydawnictwo Psychologiczne, Gdańsk.

Szukalski, P. (2008), “Ageizm - dyskryminacja ze względu na wiek”, in: Kowalewski, J. T., Szukalski, P. (Eds.), Starzenie się ludności Polski - między demografia a gerontologia społeczna, Wydawnictwo Uniwersytet Łódzki, Łódź, pp. 6-22.

Van der Heijde, C. M., Van der Heijden, B. I. J. M. (2006), "A competence-based and multi-dimensional operationalization and measurement of employability", Human Resource Management, Vol.45 No. 3, pp. 449-476.

Van der Heijden, B. I. J. M., Bakker, A. B. (2011), "Toward a mediation model of employability enhancement: a study of employee--supervisor pairs in the building sector", Career Development Quarterly, Vol. 59 No. 3, pp. 232-248. DOI: http://dx.doi. org/10.1002/j.2161-0045.2011.tb00066.x

Van Selm, M., Van der Heijden, B. I. J. M. (2013), "Communicating employability enhancement throughout the life-span: a national intervention program aimed at combating age-related stereotypes at the workplace", Educational Gerontology, Vol. 39 No. 4, pp. 259-272. DOI: http://dx.doi.org/10.1080/03601277.2013.750965

Vanhercke, D., De Cuyper, N., Peeters, E., De Witte, H. (2014), "Defining perceived employability: a psychological approach", Personnel Review, Vol. 43 No. 4, pp. 592-605. DOI: http://dx.doi.org/10,1108 / PR-07-2012-0110

Watermeyer, B. (2014), "Disability and Lose: The Psychological Commodification of Identify", Psychology Journal, Vol. 11 No. 2, pp. 99-107.

Warzecha, A. (2014), "Zarządzanie różnorodnością-płeć na rynku pracy”, in: Król, M., Warzecha, A., Zieliński, M. (Eds.), Funkcja personalna w przedsiębiorstwie. Zakres, pomiar realizacji, uwarunkowania, CeDeWu.pl., Warszawa, pp. 21-29.

Wiśniewska, S. (2015), „Zatrudnialność - pojęcie, wymiary, determinanty”, Edukacja Ekonomistów i Menedżerów, Vol. 1 No. 35, pp. 11-24.

White, M. J., White, G. B. (2006), "Implicit and explicit occupational gender stereotypes", Sex Roles, Vol. 55 No. 1, pp. 259-266.

Wojciszke, B. (2004), Człowiek wśród ludzi. Zarys psychologii społecznej, SCHOLAR, Warszawa.

York, M., Knight, P. T. (2006), Embedding employability into the curriculum, The Higher Education Academy, United Kingdom. 